\title{
PENGUJIAN POTENSI BAKTERI ENDOFIT TERHADAP PERTUMBUHAN POPULASI NEMATODA SISTA KUNING (Globodera rostochiensis) PADA TANAMAN KENTANG (Solanum tuberosum L.)
}

\author{
Ulfah Utami $^{1}$, Lilik Hariani ${ }^{2}$, Retno Setyaningrum ${ }^{3}$ \\ ${ }^{1}$ Staf Pengajar Jurusan Biologi, Fakultas Sains dan Teknologi, UIN Maliki Malang \\ ${ }^{2}$ Staf Pengajar Jurusan Biologi, Fakultas Sains dan Teknologi, UIN Maliki Malang \\ ${ }^{3}$ Mahasiswa Jurusan Biologi, Fakultas Sains dan Teknologi, UIN Maliki Malang
}

\begin{abstract}
ABSTRAK
Yellow Nematoda sista (Globodera rostochiensis) is one of interfering plant organism in potatoes plants that bothers farmers in Indonesia. Many controls done by farmers during this time uses chemist pesticide. The using of chemist pesticide continuously can threaten human environment and healthy. The existence of endofit bacteria might became one of nematode controlling agent which is hospitable, because endofit bacteria can produce toxic compound in nematode. The aim of this research is to find out the filtrate potential of endofit bacteria to the growth of yellow nematode sista population (Globodera rostochiensis) in potatoes plants. This research is done in Microbiological and Greenhouse Laboratory, Biology Department, Science and Technology Faculty, UIN Maulana Malik Ibrahim Malang and Pest and Plant Disease Laboratory, Agriculture Faculty, Universitas Brawijaya Malang. This research is done in December 2011 until April 2011 by using Rancangan Acak Lengkap (RAL) method. Bacterial filtrate is made in a way of making endofit bacteria grow in TSB media for 48 hours, then disentrifugasi with speed $13.000 \mathrm{rpm}$ for 15 minutes. Next, it is tested in yellow nematode sista in potatoes plants in the greenhouse. The result of this research shows that endofit bacteria filtrate can obstruct the growth of sista Globodera rostochiensis population. Three from those six isolates which have high ability in pressing sista Globodera rostochiensis population in 100 gram of soil are isolate AA (91\%), DH (81\%) and BE (81\%). Isolate AA can press sista Globodera rostochiensis population in the high scale, which reach until 91\%. All endofit bacteria isolate (Isolat AA, AH, BA, BE, DA and $D H)$ can increase the growth of potatoes plants, they are the height of plant and the weight of potatoes plants root.
\end{abstract}

Keywords: Solanum tuberosum L., Endofit Bacteria, Yellow Nematoda Sista (Globodera rostochiensis)

\section{A. PENDAHULUAN}

Kentang (Solanum tuberosum L.) merupakan bahan pangan yang terpenting ke-4 di dunia setelah gandum, jagung dan beras (Rowe, 1993 dalam Fitriyani, 2009). Kentang mengandung nilai karbohidrat tertinggi kedua setelah serealia (Jatala \& Bridge, 1990 dalam Fitriyani, 2009). Di Indonesia, kentang juga merupakan komoditas holtikultura yang penting dan telah menjadi bahan pangan alternatif yang dapat menunjang program diversifikasi pangan.

Salah satu faktor resiko dalam usaha tani kentang sejak di lapangan sampai di penyimpanan adalah 
Pengujian Potensi Bakteri Endofit Terhadap ...

adanya serangan Organisme Pengganggu Tumbuhan (OPT). OPT yang meresahkan petani kentang pada saat ini adalah Nematoda Sista Kuning (NSK). Tingkat kerusakan yang disebabkan oleh serangan NSK dapat mencapai 50-75 \%, dan mengakibatkan penurunan produksi kentang. Sebagai contoh, potensi produksi pada lahan seluas 1,5 ha yang biasanya mencapai 24 ton menjadi 12 ton bahkan tinggal 8 ton (Deptan, 2005).

Nematoda Sista Kuning dilaporkan pertama kali ditemukan di Indonesia di dusun Sumber Brantas, Desa Tulung Rejo, Kecamatan Bumi Aji, Kota Batu Malang, Jawa Timur (Mulyadi et al., 2003).

Pengendalian hama nematoda sista kuning yang paling banyak dilakukan saat ini adalah menggunakan nematisida kimia. Cara pengendalian nematoda dengan menggunakan nematisida kimiawi dapat menimbulkan dampak negatif berupa keracunan pada manusia dan hewan peliharaan, pencemaran air tanah, serta terbunuhnya organisme bukan sasaran, termasuk musuh alami nematoda seperti jamur dan bakteri (Mustika dan Nuryani, 2006).

Salah satu alternatif baru pengendalian nematoda yang ramah lingkungan adalah pemanfaatan bakteri endofit.. Li et al. (2002) melaporkan bahwa produksi senyawa toksik dalam kultur filtrate dari bakteri endofit Bulkholderia ambifaria berasal dari akar tanaman jagung dapat menghambat penetasan telur dan mobilitas dari larva stadia kedua M. Incognita. Harni et al. (2006), juga melaporkan bahwa isolat bakteri endofit dari genera Bacillus sp. mempunyai kemampuan yang tinggi dalam menekan populasi nematoda peluka akar Pratylenchus brachyurus pada nilam.

Tujuan dari penelitian ini adalah untuk mengetahui potensi filtrate bakteri endofit terhadap pertumbuhan populasi Nematoda Sista Kuning (Globodera rostochiensis) pada tanaman kentang (Solanum tuberosum L.)

\section{B. METODE PENELITIAN 1. Rancangan Penelitian}

Penelitian ini merupakan penelitian eksperimental. Rancangan yang digunakan dalam penelitian ini adalah rancangan acak lengkap (RAL) tunggal, dengan 7 perlakuan dan 3 kali ulangan.

\section{Waktu dan Tempat Penelitian}

Penelitian ini dilaksanakan pada bulan Desember 2011 sampai dengan April 2012, di Laboratorium Mikrobiologi dan Greenhouse Jurusan Biologi, Fakultas Sains dan Teknologi, Universitas Islam Negeri (UIN) Maulana Malik Ibrahim Malang dan Laboratorium Nematologi Jurusan Hama dan Penyakit Tumbuhan (HPT) Fakultas Pertanian Universitas Brawijaya Malang.

\section{Isolat bakteri endofit}

Isolat bakteri endofit (Isolat AA, $\mathrm{AH}, \mathrm{BA}, \mathrm{BE}, \mathrm{DA}, \mathrm{DH})$ diperoleh dari hasil isolasi bakteri endofit tanaman kentang yang ditanam di lahan pertanian kentang Desa Sumber Brantas Batu Malang.

\section{Nematoda sista kuning}

Nematoda sista kuning ( Globodera rostochiensis) diisolasi berdasarkan metode Ditlin (2008).

\section{Bibit tanaman kentang}

Bibit atau umbi kentang (Solanum tuberosum .L) yang digunakan dalam penelitian ini adalah umbi kentang bersertifikat yang rentan terhadap serangan 
nematoda sista kuning (Globodera rostochiensis) varietas Granola. Berat umbi kentang antara 100-120 gram dengan 3-5 mata tunas, kemudian dicuci hingga bersih kemudian dibilas dengan air steril.

\section{Prosedur Penelitian}

\section{a. Pembuatan Kultur Filtrat Bakteri Endofit}

Bakteri endofit yang digunakan ditumbuhkan pada media Tryptic Soy Agar (TSA) selama 24 jam pada suhu kamar. Koloni tunggal dari bakteri dipindahkan ke dalam $100 \mathrm{ml}$ media Tryptic Soy Broth (TSB) kemudian diinkubasi pada suhu $25^{\circ}$ $\mathrm{C}$ menggunakan shaker incubator selama 48 jam dengan kecepatan 150 rpm. Kemudian kultur bakteri disentrifugasi dengan kecepatan $13.000 \mathrm{rpm}$ selama 15 menit. Filtrat bakteri endofit diambil dan dipergunakan dalam pengujian.

\section{b. Penanaman Bibit Kentang}

Bibit umbi kentang ditanam dalam pot yang berisi tanah steril (tanah:pasir, 2 : 1) sebanyak 2 $\mathrm{kg} /$ polibag, dimasukkan dalam polibag berukuran $15 \times 35 \mathrm{~cm}$. Lubang tanam dibuat dengan kedalaman 8-10 cm. Bibit dimasukkan ke lubang tanam, ditimbun dengan tanah dan tekan tanah di sekitar umbi.Tiap polibag tanaman kentang teridiri dari 1 tanaman, sehingga polibag yang memliki tanaman lebih dari 1 akan dicabut. Untuk mengganti tanaman yang kurang baik, maka dilakukan penyulaman. Bibit kentang varietas Granola yang telah bertunas disemai selama 5 hari ditanam pada polibag.

\section{c. Perlakuan Filtrat Bakteri Endofit}

Tanah disekitar batang tanaman kentang disiram dengan filtrat bakteri endofit, masing-masing $10 \mathrm{ml}$ per polibag.

\section{d. Inokulasi Nematoda sista kuning \\ Inokulasi nematoda sista kuning} (Globodera rostochiensis\} dilakukan 2 minggu setelah perlakuan ditanam, dengan cara 100 ekor larva II diinokulasikan dengan cara menuangkan suspensi nematoda di sekitar batang tanaman (Harni, 2006).

Pemeliharaan tanaman kentang dilakukan dengan cara penyiangan minimal dua kali selama masa penanaman. Penyiangan dilakukan pada fase kritis yaitu vegetnatif awal dan pembentukan umbi.Tanaman kentang sangat peka terhadap kekurangan air. Pengairan dilakukan secara rutin tetapi tidak berlebihan. Pemberian air yang cukup membantu menstabilkan kelembaban tanah. Pemberian air selang waktu 7 hari sekali secara rutin sudah cukup untuk tanaman kentang. Pengairan dilakukan dengan cara disiram sampai areal lembab.

\section{e. Pengamatan Jumlah Sista Globodera rostochiensis dalam 100 gram Tanah}

Penghitungan jumlah sista Globodera rostochiensis dalam 100 gram tanah dilakukan pada 7 minggu setelah penanaman kentang. Pengambilan sista dilakukan dengan metode flotasi (Fenwick) mula-mula diambil tanah 100 gram kemudian ditambahkan air lalu diaduk dan didiamkan selama 5 menit agar tanah bisa mengendap dan yang tersisa hanya bahan-bahan organik dan nematoda sista kuning yang mengapung di tepi beaker glass, kemudian ditambahkan air sampai melimpah (air yang melimpah terdiri dari bahan organik dan nematoda sista kuning), kemudian ditampung dan diambil nematoda yang ada pada 
Pengujian Potensi Bakteri Endofit Terhadap ...

baki dengan kuas kecil (Rahayu, 2003).

\section{f. Pengamatan Terhadap Tinggi Tanaman Kentang. \\ Tanaman kentang dicabut dari dalam tanah, kemudian diletakkan diatas lantai bersih dan diukur panjang tanaman mulai dari ujung hingga pangkal dengan menggunakan mistar.}

\section{g. Pengamatan Terhadap Berat}

\section{Akar Tanaman Kentang}

Akar tanaman kentang yang telah dicabut dari tanah dan dibersihkan, kemudian ditimbang berat akar dengan menggunakan timbangan analitik.

\section{h. Analisa Data}

Analisis penelitian ini melalui Uji Anova One Way. Apabila $F_{\text {hitung }}$ $>\mathrm{F}_{\text {tabel }} 5 \%$, maka $\mathrm{H}_{0}$ ditolak. Apabila terjadi perbedaan yang nyata, maka dilanjutkan dengan uji BNT dengan taraf signifikansi 5\%.

\section{HASIL DAN PEMBAHASAN \\ 1. Pengaruh Pengaruh Filtrat Bakteri Endofit dalam Menghambat Populasi nematode Sista kuning (Globoderarostochiensis) dalam 100 gram Tanah pada Tanaman Kentang.}

Berdasarkan hasil penelitian yang telah dilakukan dengan uji statistik menggunakan (ANOVA) menunjukkan bahwa $F_{\text {hitung }}>F_{\text {tabel }}$ 0,05 yang berarti bahwa aplikasi filtrat bakteri endofit mampu menurunkan populasi nematode sista kuning pada tanaman kentang.

Berdasarkan uji lanjut dengan BNT pada taraf 5\%, menunjukkan bahwa perlakuan kontrol memberikan nilai tertinggi, hal ini dikarenakan pada perlakuan kontrol tidak ada penambahan filtrat bakteri endofit. Populasi sista Globodera rostochiensis pada kontrol dengan tanaman kentang yang diaplikasikan menggunakan filtrat bakteri endofit menunjukkan perbedaan yang nyata. Hal ini menunjukkan bahwa filtrat bakteri endofit (isolat bakteri $\mathrm{AH}$, $\mathrm{DA}, \mathrm{BA}, \mathrm{BE}, \mathrm{DH}$, dan $\mathrm{AA})$ dapat digunakan untuk menghambat pertumbuhan nematoda sista kuning. Antara semua isolat bakteri endofit tidak menunjukkan perberbedaan yang nyata dalam menghambat populasi sista Globodera rostochiensis, kecuali pada isolat $\mathrm{AH}$. Pada isolat $\mathrm{AH}$ menunjukkan perbedaan yang nyata dibandingkan dengan isolat yang lain dalam menghambat populasi nematoda sista kuning (Globodera rostochiensis).

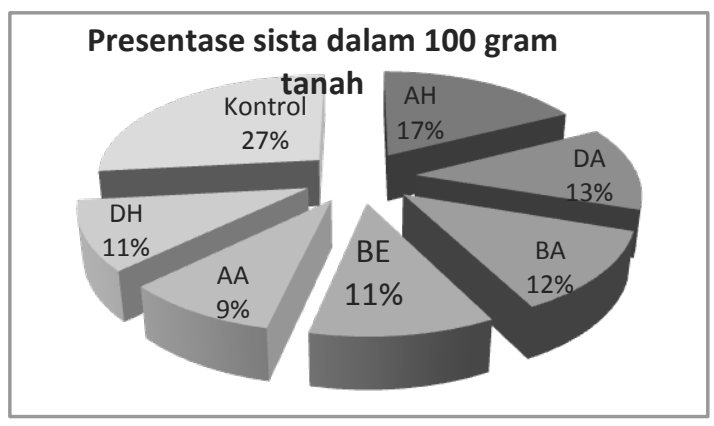

Gambar 1. Diagram populasi nematode sista kuning (G. Rostochiensis) dalam 100 gram tanah

Persentase kehidupan nematoda sista kuning (G. Rostochiensis) dalam tanah yang diberi perlakuan dengan fitrat bakteri endofit dan tanpa perlakuan menunjukkan perbedaan yang cukup jauh. Pada kontrol persentase populasi nematoda sista kuning $27 \%$ (Gambar. 1) lebih tinggi dibandingkan dengan tanaman yang diberi perlakuan filtrat bakteri endofit.

Tingginya jumlah sista yang terdapat dalam kontrol menunjukkan bahwa larva II yang diinokulasikan telah berkembang, sehingga tanaman kentang tersebut terserang oleh 
nematoda sista kuning. APHIS (2008), menyatakan bahwa menetasnya telur terjadi ketika faktor lingkungan dalam kondisi yang tepat dan kehadirannya akan tersebar pada akar tanaman inang suku Solanaceae, termasuk pada tanaman kentang. Telur menetas ketika pada kondisi optimal. Ketika larva II menemukan inang, maka akan masuk ke dalam akar melalui ujung pertumbuhan akar atau melalui akar lateral dan menggunakan mulut atau stylet-nya untuk menembus dinding sel dan membentuk Synctium.

Adapun isolat yang memiliki kemampuan tinggi dalam menekan populasi nematoda sista kuning adalah isolat AA, yaitu dengan jumlah sista paling sedikit 9\% dibandingkan dengan isolat yang lain. Rendahnya populasi nematoda sista kuning (Globodera rostochiensis) dalam tanah yang diberi perlakuan isolat filtrat bakteri endofit menunjukkan bahwa adanya senyawa-senyawa kimia tertentu yang dihasilkan oleh isolat filtrat bakteri endofit, seperti siderofor, fitoaleksin dan juga senyawa antinematoda yang dapat menghambat pertumbuhan nematoda.

Mekanisme bakteri endofit dalam menginduksi ketahanan adalah dengan mengkolonisasi jaringan dalam tanaman sehingga menstimulasi tanaman untuk meningkatkan produksi senyawa metabolit yang berperan dalam ketahanan tanaman, di antaranya enzim peroksidase, peningkatan aktifitas kitinase, $\beta-1,3$ glucanase, pathogenesis related protein dan fitoaleksin (Press et al., 1997). Enzim peroksidase dibutuhkan oleh tanaman untuk menghasilkan senyawa-senyawa pertahanan tanaman seperti lignin, kitin dan beberapa senyawa penyusun dinding sel (Hallmann, 2001).

Berdasarkan pengujian yang telah dilakukan terhadap beberapa isolat, populasi sista yang paling rendah terdapat pada isolat $\mathrm{AA}$ yang berasal dari akar tanaman kentang. Isolat AA mampu menghambat populasi sista hingga $91 \%$, hal ini dapat dikarenakan isolat AA menghasilkan senyawa-senyawa kimia yang lebih banyak dibandingkan dengan isolat yang lain, dimana senyawa-senyawa yang dihasilkan isolat AA ini mampu berasosiasi dengan tanaman kentang sehingga dapat mencegah perkembangan Globodera rostochiensis.

Pada isolat $\mathrm{DH}$ dan $\mathrm{BE}$ yang masing-masing isolat diisolasi dari bagian batang tanaman kentang tidak berbeda jauh dengan isolat AA, keduanya juga mampu menurunkan populasi sista dalam tanah. Hal ini juga disebabkan oleh senyawasenyawa kimia hasil metabolit sekunder yang dihasilkan dari filtrat bakteri endofit yang dapat menghambat perkembangan G.rostochiensis. Begitu pula dengan isolat BA, DA dan AH tidak berbeda jauh dalam menekan populasi nematode sista kuning (Globodera rostochiensis).

Terhambat atau terbunuhnya nematoda kemungkinan disebabkan oleh adanya senyawa kimia yang dihasilkan oleh bakteri endofit. Hallman $d k k$., (1995) dalam Athman (2006), menyatakan bahwa bakteri endofit berperan dalam mengendalikan Meloidogyne incognita pada tomat.

Jumlah sista dalam tanah pada kontrol menunjukkan nilai terrtinggi dibandingkan dengan isolat yang 
Pengujian Potensi Bakteri Endofit Terhadap ...

lainnya. Hal ini disebabkan larva yang telah menginfeksi akar pada tanaman kentang telah berkembang menjadi nematoda sista kuning betina yang kemudian menjadi sista yang dapat menghasilkan telur. Sedangkan pada tanaman yang diberikan perlakuan filtrat bakteri endofit, jumlah sista memiliki nilai yang rendah dibandingkan dengan kontrol. Hal ini disebabkan larva yang telah menginfeksi akar pada tanaman kentang tidak berkembang menjadi nematode sista kuning betina. Larva mati pada tingkat awal perkembangan, sehingga larva yang berhasil menjadi G. rostochiensis betina yang kemudian akan menjadi sista hanya sedikit.

Bacon (2007) dalam Harni (2011) melaporkan bahwa bakteri endofit dalam menekan populasi nematoda diantaranya mengkolonisasi jaringan internal inang dan menempati relung ekologi yang dibutuhkan oleh patogen, (2) mengkolonisasi jaringan kortek, dan (3) menghasilkan metabolit yang dapat menekan perkembangan patogen, serta (4) menginduksi ketahanan tanaman.

\section{Pengaruh Filtrat Bakteri Endofit Terhadap Pertumbuhan Tanaman Kentang (Solanum tuberosum L.) \\ a. Pengaruh Filtrat Bakteri Endofit Terhadap Tinggi Tanaman Kentang}

Berdasarkan hasil analysis of varians (ANOVA) menunjukkan bahwa $F_{\text {hitung }}>F_{\text {tabel }} 0,05$ yang berarti bahwa perlakuan isolat filtrat bakteri endofit berpengaruh nyata terhadap pertumbuhan tinggi tanaman kentang. Hasil uji lanjut dengan menggunakan BNT 5\%, menunjukkan bahwa isolat filtrat bakteri endofit berpotensi dalam meningkatkan tinggi tanaman kentang. Pada isolat AA, DH dan BE dihasilkan rata-rata tinggi tanaman 80, 67 dan $59 \mathrm{~cm}$, hal ini menunjukkan bahwa isolat $\mathrm{AA}, \mathrm{DH}$ dan $\mathrm{BE}$ merupakan isolat yang berpotensi dalam menghambat pertumbuhan nematoda sista kuning. Adapun isolat yang paling bagus dalam meningkatkan tinggi tanaman adalah isolat AA dengan tinggi tanaman $80 \mathrm{~cm}$.

Berdasarkan hasil analisa pengaruh nematoda terhadap tinggi tanaman menunjukkan bahwa tinggi tanaman dipengaruhi oleh banyaknya jumlah nematoda yang hidup. Semakin sedikit nematoda yang hidup maka semakin bertambah tinggi tanaman. Knoxfield (2006), menyatakan bahwa tanaman yang diserang nematoda $G$. rostochiensis akan menjadi kerdil.

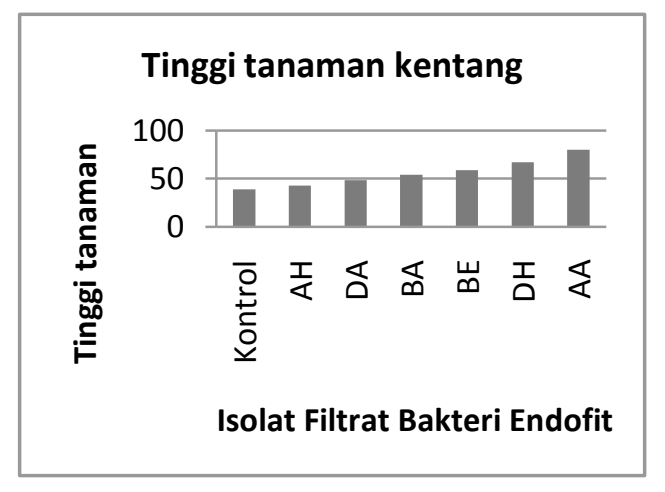

Gambar 2. Diagram pengaruh filtrat bakteri endofit terhadap tinggi tanaman kentang

Hasil penelitian Tirta (2007), menyatakan bahwa tinggi tanaman merupakan salah satu peubah dari pertumbuhan vegetatif yang dapat diamati untuk melihat pengaruh inokulasi dan pemupukan nitrogen. Hasil uji menunjukkan bahwa dengan pemberian perlakuan bakteri endofit berpengaruh nyata terhadap tinggi tanaman jagung dan mampu 
meningkatkan tinggi tanaman dibandingkan dengan kontrol.

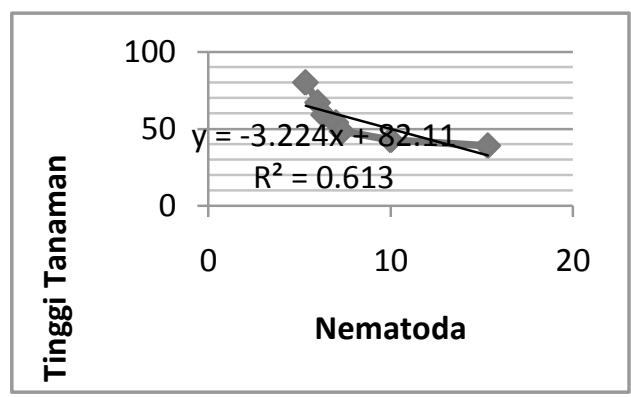

Gambar 3. Grafik hasil analisa regresi polynomial pengaruh jumlah nematode sista kuning (G.rostochiensis) terhadap tinggi tanaman

Hasil analisa menggunakan regresi polynomial menunjukkan bahwa jumlah sistaGlobodera rostochiensis mempengaruhi tinggi tanaman kentang sebesar $61,3 \%$.

Tanaman yang diberi perlakuan filtrat bakteri endofit memiliki tinggi yang lebih dibandingkan dengan kontrol, hal ini dipengaruhi oleh jumlah sista yang terdapat pada tanaman kentang. Tanaman yang diserang nematoda akan menjadi kerdil hal ini karena nutrisi yang terdapat pada tanaman kentang telah diserap oleh nematoda sehingga kebutuhan nutrisi yang dibutuhkan oleh tanaman kentang untuk tumbuh dan berkembang menjadi berkurang. Kemampuan isolat filtrat bakteri endofit dalam meningkatkan tinggi tanaman kemungkinan berkaitan dengan kemampuan bakteri tersebut dalam menghambat pertumbuhan nematodasista kuning (Globodera rostochiensis) dan menghasilkan hormon pertumbuhan.

Zinniel dkk (2002), menyatakan bahwa selain mampu melindungi tanaman dari serangan patogen, kemampuan bakteri endofit dalam memfiksasi nitrogen juga membantu dalam meningkatkan tinggi tanaman.
Adanya kemampuan isolat bakteri endofit dalam meningkatkan pertumbuhan tanaman disebabkan karena bakteri endofit mampu memproduksi fitohormon, meningkatkan produksi penyerapan mineral, fiksasi nitrogen, mengurangi kerusakan akibat perubahan cuaca dan meningkatkan ketahanan tanaman dari penyakit.

Selain meyebabkan tinggi tanaman, aplikasi dengan bakteri endofit juga mengakibatkan batang tanaman menjadi lebih besar dibandingkan dengan kontrol. Lakitan (1996) dalam Kusumaningrum dkk (2007), mengatakan bahwa pertumbuhan tidak berlangsung secara seragam pada seluruh bagian tanaman. Pertumbuhan dimungkinkan terfokus pada jaringan meristem batang sehingga pembesaran sel yang dihasilkan dari pembelahan sel tersebut yang menyebabkan pertambahan ukuran tanaman.

\section{b. Pengaruh Filtrat Bakteri Endofit Terhadap Berat Akar Tanaman Kentang}

Berdasarkan hasil analisa menggunakan uji statistik dengan Analisis Of Variance, menunjukkan $\mathrm{F}_{\text {hitung }}>\mathrm{F}_{\text {tabel }} 0,05$, yang berarti ada pengaruh inokulasi filtrat bakteri endofit terhadap peningkatan berat akar tanaman kentang, yang kemudian dilakukan uji lanjut menggunakan uji BNT (Beda Nyata Terkecil) dengan taraf signifikan 5\% menunjukkan bahwa ada perbedaan yang nyata antara berbagai macam jenis isolat yang digunakan dalam mempengaruhi berat akar tanaman kentang.

Hasil uji lanjut menggunakan uji BNT (Beda Nyata Terkecil) dengan taraf signifikan 5\% menunjukkan bahwa ada perbedaan yang nyata 
Pengujian Potensi Bakteri Endofit Terhadap ...

antara beberapa macam isolat yang digunakan, dan isolat yang berpotensi dalam meningkatkan berat akar tanaman adalah isolat AA, DH dan BE (Gambar 4).

Ketiga jenis isolat mampu meningkatkan berat akar tanaman kentang dikarenakan tingginya kemampuan ketiga jenis isolat tersebut dalam meningkatkan berat akar, dikarenakan oleh adanya senyawa kimia atau antibiotik tertentu yang dihasilkan. Sehingga bakteri endofit mampu melindungi tanaman dari serangan nematoda Globodera rostochiensis.

Akar menentukan kemampuan tanaman untuk menyerap nutrisi dan air, pertumbuhannya ditentukan oleh area daun yang aktif melakukan fotosintesis karena akar bergantung pada penangkapan energy oleh daun. Pada saat suplai energi terbatas, maka energi yang ada digunakan oleh jaringan tanaman yang paling dekat dengan lokasi fotosintesis. Oleh karena itu akar menerima energi hanya pada saat ada kelebihan energi yang diproduksi melalui fotosintesis yang tidak digunakan untuk pertumbuhan bagian atas dari tanaman (Dewi, 2007).

Besarnya nilai panjang akar dan berat akar yang diinokulasikan dengan filtrat bakteri endofit dibandingkan kontrol menunjukkan adanya proses ketahanan yang dibangun oleh filtrat bakteri endofit bagi tanaman inang. Hal ini secara tidak langsung menunjukkan bahwa bakteri terlebih dahulu menekan pertumbuhan mikroorganisme pengganggu melalui mekanisme kompetisi, predasi, dan antibiotik yang dihasilkannya (Kloepper $d k k$. 1991 dalam Harni et al., 2007).

Terjadinyapeningkatan pertumbuhan, seperti berat akar, disebabkan oleh karena bakteri endofit dapat merangsang pembentukan akar lateral dan jumlah akar sehingga dapat memperluas penyerapan unsur hara.

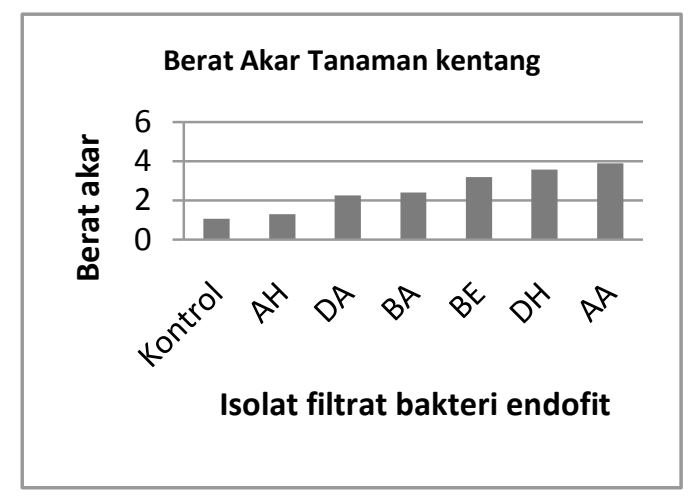

Gambar 4. Diagram batang berat akar tanaman kentang

Bacon dan Hinton (2007) melaporkan bahwa bakteri endofit dapat meningkatkan pertumbuhan tanaman dengan cara: 1) meningkatkan ketersediaan nutrisi tanaman, seperti nitrogen, fosfat, fosfor dan mineral lainnya, 2) merangsang pertumbuhan dengan memproduksi hormon pertumbuhan, seperti etilen, auxin, dan sitokinin, 3) mengurangi dampak negatif dari patogen.

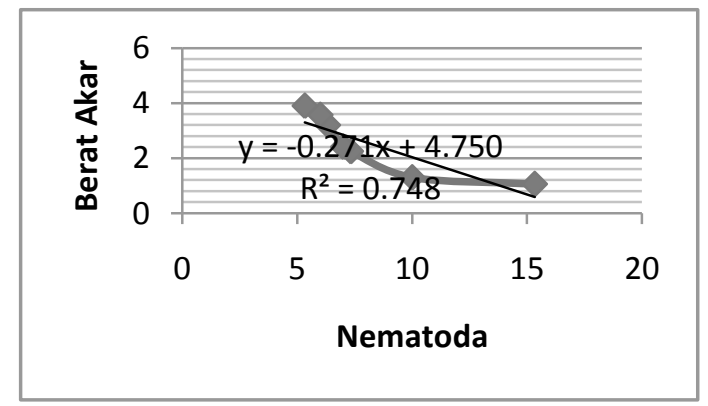

Gambar 5. Grafik hasil analisa regresi polynomial pengaruh jumlah nematode sista kuning

( G.rostochiensis) terhadap berat akar tanaman kentang

Hasil analisa menggunakan regresi polynomial menunjukkan bahwa jumlah sista G. rostochiensis 
mempengaruhi berat akar tanaman kentang sebesar 74, 87\% (Gambar 5).

Rendahnya berat akar tanaman yang diinokulasi nematoda, disebabkan oleh kerusakan akibat penusukan stilet dan sekresi enzim yang dikeluarkan nematoda sewaktu nematoda makan. Agrios (1997) dalam Harni (2007), melaporkan bahwa nematoda yang mengkonsumsi sel akar mampu menurunkan kemampuan tumbuhan menyerap air dan hara dari tanah sehingga menyebabkan gejala seperti kekurangan air dan hara. Disamping itu, nematoda juga menyebabkan berkurangnya konsentrasi zat pengatur tumbuh tanaman seperti auksin, sitokinin, dan giberelin yang banyak terdapat di ujung akar. Berkurangnya zat pengatur tumbuh dapat terjadi karena nematoda mengeluarkan enzim selulase dan pektinase yang mampu mendegradasi sel sehingga ujung akar luka dan pecah, hal ini menyebabkan auksin tidak aktif. Tidak aktifnya auksin menyebabkan pertumbuhan akar terhambat.

\section{KESIMPULAN}

1. Isolat bakteri endofit (Isolat AA, $\mathrm{AH}, \mathrm{BA}, \mathrm{BE}, \mathrm{DA}, \mathrm{DH})$ yang berasal dari tanaman kentang (akar, batang dan daun) mampu menghambat pertumbuhan populasi nematode sista kuning (Globodera rostochiensis) dibandingkan dengan kontrol pada tanaman kentang.

2. Isolat filtrat bakteri endofit AA mampu menekan populasi nematoda sista kuning dalam 100 gram tanah sebesar $91 \%$.

3. Semua isolat bakteri endofit (Isolat AA, AH, BA, BE, DA, $\mathrm{DH})$ mampu meningkatkan pertumbuhan tanaman kentang, yaitu tinggi tanaman dan berat akar tanaman kentang.

\section{E. DAFTAR PUSTAKA}

APHIS (Animal and Plant Health Inspection Service). 2008. Golden Nematoda Ro2 Eradication in Livingston and Suffolk Counties, New York. http://www.aphis.usda.gov/plant_ health/ea/downloads/goldennematode - ea-9-08-pdf. Diakses tanggal 10 November 2011.

Athman, S. Y. 2006. Review of the role of endophytes in biological control of plant-parasitic nematodes with special reference to the banana nematode, Radopholus similes (Cobb) Thourne. University of Pretoria.Pp528.http://www.upetd. up.ac.za/thesis/available/etd12072006-105803/

$\begin{array}{llr}\text { unrestricted/01 chapter } & 1 . \\ \text { Diakses pada tanggal } & 09 \\ \text { November 2011. } & & \end{array}$

Bacon, C.W. and S.S. Hinton. 2007. Bacterial endophytes: The endophytic nische, its occupants, and its utility. Dalam: Gnanamanickam SS. Gnanamanickam (ed.). PlantAssociated Bacteria. Springer, Berlin. pp. 155-194.

Deptan.2005. Pengenalan dan Pengendalian

NSK(http://ditlin.hortikultura.dep $\tan$.

go.id/makalah/nsk_kentang.html) . Diakses tanggal 10 November 2011.

Dewi, Intan Ratna. 2007. Fiksasi $N$ Biologis pada Ekosistem Tropis. http://pustaka.unpad.ac.id/wpcontent/uploads/rhizobia_mklh_1 .pdf. Akses 1 Mei 2012. 
Pengujian Potensi Bakteri Endofit Terhadap ...

Ditlin. 2008. Pengenalan dan Pengendalian NSK (Nematoda Sista Kuning). http://ditlin.hortikultura.deptan.g o.id/makalah/nsk_kentang.html.

Diakses pada tanggal 10 November 2011.

Fitriyani, Dewi., Mulyadi., Cristanti, Sumardiono, 2009. Mekanisme Ketahanan kentang terhadap Nematoda Sista Kuning. Jurnal HPT Tropika. ISSN 1411-7325. Vol.9 No.1:46-53. Maret 2003.

Hallmann, J. 2001. Plant interaction with endophytic bacteria. Dalam : Jeger, M.J. and N.J. Spence (eds.). Biotic Interaction in PlantPathogen Associations. $\mathrm{CAB}$ International.

Hallmann, Johannes. 1999. Plant Interactions with Endophytic Bacteria.http://www.bspp.org.uk/ archives/bspp1999/session3.php.

Diakses tanggal 12 November 2011.

Harni, R., Munif, A., Mustika, I. 2006. Potensi Metode Aplikasi Bakteri Endofit terhadap Perkembangan Nematoda Peluka Akar (Pratylenchus brachhyurus) pada Tanaman Nilam. Jurnal Littri 12(4), ISSN 0853-8212.

Harni, Rita., Munif, Abdul., Supramana., Mustika, Ika. 2007. Potensi Bakteri Endofit Pengendali Nematoda Peluka Akar (Pratylenchus Brachyurus) Pada Nilam. HAYATI Journal of Bioscience. Vol. 14, No. 1

Knoxfield, Berg Gordon. 2006. Potato Cyst Nematode. http://www.dpi. vic.gov.au/DPI/nreninf.nsf/childd ocs/71E8091F577D52D24A2568 B300 $04 F 3 B$ open. Diakses tanggal 12 November 2011.

Kusumaningrum, Indri., Hastuti, Rini Budi., dan Haryanti, Sri. 2007.
Pengaruh Perasan Sargassum crassifolium dengan Konsentrasi yang Berbeda terhadap Pertumbuhan Tanaman Kedelai (Glycine max (L) Merill). Buletin Anatomi dan Fisiologi, Vol. XV, No. 2.

Mulyadi, B. Rahayu, B. Triman, \& S. Indarti. 2003. Identifikasi Nematoda Sista Kuning (Globodera rostochiensis) Pada Kentang Di Batu, Jawa Timur. Jurnal Perlindungan Tanaman Indonesia. 9(1): 46-53.

Mustika, Ika dan Nuryani, Yang. 2006. Strategi Pengendalian Nematoda Parasit pada Tanaman Nilam. Jurnal Litbang Pertanian, 25(1).

http://www.pustakadeptan.go.id/publikasi/p3251062. $p d f$. Akses 7 Mei 2009.

Press, C., W. Kisaalita, M. Wilson, S. Tuzun, And J.W. Kloepper. 1997. Effects of iron and siderophores on induce systemic resistance on cucumber mediated by Serratia marcescens 90-166. Dalam: Ogoshi, A., K. Kobayashi, K. Homma, F. Kodama, N. Kondo, and S. Akino (eds). Plant growthpromoting

Rahayu, B. 2003. Teknik Ekstraksi dan Identifikasi Nematoda Sista Kuning. Makalah Lokakarya Nematoda Sista Kuning pada Tanggal 1-12 Maret 2003. Yogyakarta. Hlm 1-4.

Tirta, I Gede. 2007. Pengaruh Beberapa Jenis Media Tanam dan Pupuk Daun terhadap Pertumbuhan Vegetatif Anggrek Jamrud (Dendrobium macrophyllum A. Rich.). B I O D I V E R S I T A S.

Zinniel, Denise K., Anne K. 2002. Isolation and Characterization of 
Endophytic Colonizing Bacteria from Agronomic Crops and Prairie Plants. Applied And Environmental Microbiology, 74 Vol. 68, no. 5. American Society for Microbiology. Plant Pathology Department Papers in Plant Pathology. 